\title{
REFERENCE
}

\section{All106 690489}

\section{NBSIR 75-701}

\section{Evaluation of Smokeproof Stair Towers and Smoke Detector Performance}

Francis C. W. Fung and Richard H. Zile

Center for Fire Research

Institute for Applied Technology

National Bureau of Standards

Washington, D.C. 20234

September 1975

Final

\section{Prepared for}

Office of Policy Development and Research Department of Housing and Urban Development

QC

Washington, D.C. 20410 



\section{EVALUATION OF SMOKEPROOF STAIR} TOWERS AND SMOKE DETECTOR PERFORMANCE

Francis C. W. Fung and Richard $\mathrm{H}$. Zile

Center for Fire Research

Institute for Applied Technology

National Bureau of Standards

Washington, D.C. 20234

September 1975

Final

Prepared for

Office of Policy Development and Research

Department of Housing and Urban Development

Washington, D.C. 20410

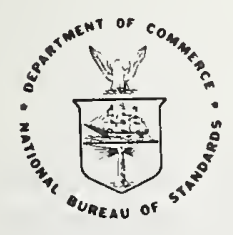

U.S. DEPARTMENT OF COMMERCE, Rogers C.B. Morton, Secretary James A. Baker, III, Under Secretary Dr. Betsy Ancker-Johnson. Assistant Secretary for Science arid Technology 
Smoke as a critical factor in the safety of persons in a fire situation in a high-rise building has received considerable attention in recent years $[1,2]^{1}$. In case of fire in such a structure, the initial buoyancy forces due to heat may be augmented by a stack effect resulting from weather conditions to cause air and smoke to travel more rapidly upwards in stairways and elevator and utility shafts. This vertical movement of smoke not only speeds smoke infiltration into the upper levels of a building, but can also leave travel paths clogged with smoke, thus hindering or preventing evacuation and obstructing the efforts of firefighters.

Recent research abroad and in the United States has indicated the feasibility of smoke control by means of ventilation make-up, air input, and pressurization or venting of the stairwells. From a brief survey of the current status of smoke control in high-rise buildings it appears that the basic principles and guidelines for these techniques are being studied widely [3-12]. For a more detailed literature discussion, refer to Hobson and Stewart's article [13]; and for general guidelines on high-rise smoke control, see the work by Galbreath, McGuire and Tamura [14].

Current smoke control activities at the National Bureau of standards (NBS) are aimed at evaluating the techniques quantitatively. With this in mind two approaches have been taken: first, to conduct high-rise smoke simulation experiments that can quantitatively measure the smoke movement under controlled and uncontrolled conditions; and second, to model the smoke simulation experiments analytically: to establish a smoke movement prediction program which will form the basis for optimizing smoke control design standards.

$\overline{1}$ Numbers in brackets refer to the literature references listed in section 8 . 
In view of the present accepted practice in this country for building technology, common U. S. units of measurement have been used throughout this paper. In recognition of the position of the United States as a signatory to the General Conference on Weights and Measures, which gave official status to the metric SI system of units in 1960 , assistance is given to the reader interested in making use of the coherent system of SI units by giving conversion factors applicable to U. S. units used in this paper.

1 in $=0.0254 \mathrm{~m}$ (exactly)

$1 \mathrm{ft}=0.3048 \mathrm{~m}($ exactly)

$1 \mathrm{ft} / \mathrm{min}(\mathrm{fpm})=5.08 \times 10^{-3} \mathrm{~m} / \mathrm{s}$

$1 \mathrm{ft}^{3} / \mathrm{min}(\mathrm{cfm})=4.719 \times 10^{-4} \mathrm{~m}^{3} / \mathrm{s}$

1 in $\mathrm{H}_{2} \mathrm{O}=248.84$ pascal (pa) 
FOREWORD . . . . . . . . . . . . . . . i ii

SI CONVERSION UNITS .............. . . iv

LIST OF TABLES . . . . . . . . . . . . vi

1. INTRODUCTION .................. 1

2. TEST BUILDING . . . . . . . . . . . 2

3. TEST METHOD AND INSTRUMENTATION SMOKEPROOF STAIR TOWERS . . . . . . . . . 4

4. TEST METHOD AND INSTRUMENTATION SMOKE DETECTORS . . . . . . . . . . 5

5. RESULTS • • • . • . • • • • • . . . 6

5.1. Tests of Smokeproof Stair Towers . . . 6

5.2. Laboratory Test of Smoke Detectors . . . 7

5.3. Field Tests of Smoke Detectors . . . 7

6. DISCUSSION OF RESULTS . . . . . . . . . 7

7. CONCLUSIONS \& RECOMMENDATIONS . . . . . . 9

8. REFERENCES ............... 10

APPENDIX A . . . . . . . . . . . . 17

APPENDIX B . . . . . . . . . . . . . 17 


\section{LIST OF TABLES}

Page

Table 1. Smoke Movement Test 1... . . . . . 12

Table 2. Smoke Movement Test 2 (Study of Door Openings) . . . . . . . . . 13

Table 3. Smoke Detector Laboratory Tests . . . . 14

Table 4. Smoke Detector Field Tests . . . . . . 15

Table 5. Visual Observations of Smoke Detector Field Tests ............ 16 


\section{EVALUATION OF SMOKEPROOF STAIR TOWERS AND SMOKE DETECTOR PERFORMANCE}

\section{Francis C. W. Fung and Richard H. Zile}

A study was made by the National Bureau of Standards to evaluate the effectiveness of a smokeproof stairwell tower installed in a highrise apartment building. Tests were also made of photoelectric-type corridor smoke detectors. A quantitative experimental technique of smoke simulation and smoke movement measurement was used. Factors diminishing the effectiveness of the stair towers, preventing smoke infiltration and limiting the response of the detectors, are noted.

Key words: High-rise buildings; photoelectric smoke detector; smoke control; smoke movement simulation; smokeproof tower.

\section{INTRODUCTION}

Smokeproof towers and an accessory corridor smoke detection system provided in a high-rise apartment building were the subjects of study by the National Bureau of Standards (NBS).

The building had been constructed under the operation BREAKTHROUGH program of the Department of Housing and Urban Development (HUD). The "Guide Criteria for the Evolution of Operation BREAKTHROUGH Housing Systems" [15], prepared by the National Bureau of Standards, contains the recommendation that in apartment buildings over six stories in height, one exit stairway should be in a smoke-proof enclosure (definition in appendix $A$ ).

The housing system producer (HSP) had the option of using any suitable design method to satisfy the recommended requirement. Three satisfactory methods are described in the previously cited publication of the National Research Council of Canada, "Exploratory Paper on Control of Smoke Movement in High Buildings" [14].

Early in the BREAKTHOUGH program, the HSP requested a waiver of the Volume I MFHR (Multi-Family High Rise) Guide Criteria sections I.4.2.1 and I.4.2.2 for one of the buildings at the Jersey City Operation BREAKTHROUGH Prototype Site. 
These criteria recommend that corridor length dead ends not exceed 20 feet ( 40 feet with automatic smoke detection in corridors) and that a minimum of two exits be provided spaced at least one-half corridor length apart. The HSP, in order to meet certain constraints of this particular industrialized system, requested permission to place the required remotely-located stairways in the center core of the building. HUD granted these waivers on the basis that the NBS recommendations for certain compensating fire-safety provisions be incorporated into the design over and above the related recommendations in the Guide Criteria. The purpose of this field investigation was to evaluate elements of the alternate design to insure their life safety adequacy:

1. Smoke detectors provided in the corridors, spaced approximately 30 feet on center. These smoke detectors were to be connected to the building fire alarm system according to the recommendations of the Guide Criteria.

2. Both stairwells to be made smokeproof instead of one as called for in the Guide Criteria (Volume I, L.4.2.9).

3. A Class B, one-hour smoke barrier door to be installed to divide each floor corridor into two smokeproof areas. For structural reasons, the barrier was placed to one side of the center of the corridor length, as seen in figure 1. The door was to be self-closing and held open 'with' an electro-magnetic device, which released upon actuation of the building fire alarm system.

The other recommended safety provisions applicable to the building are listed in appendix B.

\section{TEST BUILDING}

The tests were conducted in an 18-story precast concrete apartment building; a typical floor plan is shown in figure 1. As already stated, and seen on the floor plan, the two required exit stairways were placed together in the center core of the building.

The design used by the HSP to render the stairways smokeproof was by provision of vestibules between the corridors and stairways. For smoke relief, the vestibules were vented to an adjoining shaft that ran the full height of the building and was open to the outside on alternate floors. The required smoke detectors were of the photoelectric type. 


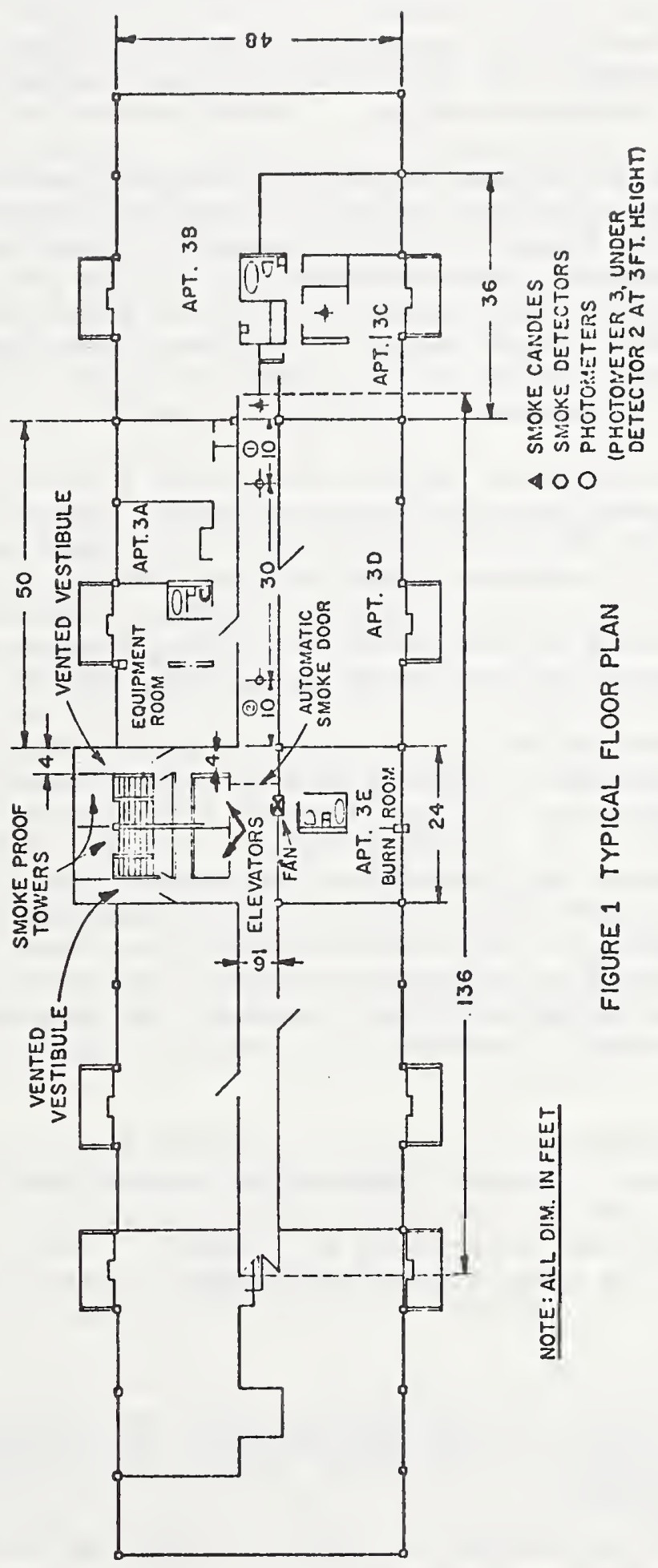




\section{TEST METHOD AND}

\section{INSTRUMENTATION-SMOKEPROOF STAIR TOWERS}

The experimental program to study the effectiveness of the smokeproof towers in the building was conducted in comparatively mild winter weather. Smoke was simulated by a net airflow out of a designated "burn-room" (third floor apartment 3E, fig. 1). The air was mixed with a predetermined precentage of sulfur hexafluoride $\left(\mathrm{SF}_{6}\right)$. tracer gas ${ }^{2}$ and heated to a temperature approximately $10^{\circ} \mathrm{F}$ above the corridor temperature. The range of reference concentrations of the $\mathrm{SF}_{6}$ tracer gas ${ }^{3}$ in the air from the burn-room was of the order of 200 parts per billion (ppb), which was the maximum reference concentration for each experiment. Two smoke movement simulations were tested, as presented in tables 1 and 2 .

The test procedures in the two trials were similar. However, as there was some indication in the first test that the effectiveness of the smokeproof towers could be defeated by the passage of persons through the isolating vestibules, the second test was conducted with people instructed to deliberately pass from the 16 th and 17 th floors into the stairwells during the period of simulated smoke release.

Prior to the beginning of each experiment the burn-room air was preheated to a temperature of approximately $80^{\circ} \mathrm{F}$ by setting the thermostat of the forced air heating furnace in that apartment. A window box-type fan as. shown in figure 1 was used to draw the preheated air from the burn-room and blow it into the corridor. A cardboard mask was installed in the hall doorway, in the same vertical plane as the fan, to allow air from the burn-room only to be channeled through the fan. The measured airflow through the fan was approximately $900 \mathrm{cfm}$ with an average pressure of approximately 0.04 inch $\mathrm{H}_{2} \mathrm{O}$ across the fan.

At the beginning of a test a standard lecture-size bottle of $\mathrm{SF}_{6}$ gas, located inside the burn-room in front of the fan, was turned on to continuously deliver a predetermined amount of $\mathrm{SF}_{6}$ to the burn-room air supply. The infiltration was then traced by sampling at different locations as tabulated in tables 1 and 2 .

\footnotetext{
${ }^{2}$ SF 6 was chosen as a tracer gas because of its electron capture property for detection, as well as being odorless, colorless, harmless and stable.

${ }^{3}$ OSHA concentration limits of $\mathrm{SF}_{6}$ is $1000 \mathrm{ppm}$ as set forth in the Federal Register, Volume 36, No. 157, August 13, 1971.
} 
Flow rates of the simulated smoke were determined from velocity measurements made with a thermo-anemomenter having a low range of 100-500 feet per minute (fpm), and a high range from 500 to $1,200 \mathrm{fpm}$. Average velocities were obtained by making a traverse of nine points as for square or rectangular ducts.

The continuous release of $\mathrm{SF}_{6}$ gas into the burn-room was metered by a ball-type flow meter with a range of 0.05 to $0.5 \mathrm{ft}^{3} / \mathrm{hr}$. In each test a slight turn of the needle valve unseated the ball to a position registering approximately $0.01 \mathrm{ft}^{3} / \mathrm{hr}$. This range of metering of $\mathrm{SF}_{6}$ diluted with the approximately $900 \mathrm{cfm}$ airflow from the burn-room usually leads to a burn-room $\mathrm{SF}_{6}$ concentration of the order of 185 $\mathrm{ppb}$. This concentration of $\mathrm{SF}_{6}$ was found to be acceptable for experimental purposes since the gas analyzer sensitivity is readable at $1 \mathrm{ppb}$. This means that the relative concentration in relation to the burn-room can be measured to one part in one hundred. Additional accuracy of the normalized measurements could be obtained by raising the burn-room $\mathrm{SF} 6$ concentration. However, an increase by an order of magnitude of burn-room $\mathrm{SF}_{6}$ concentration would lead to a doubling of the purge time between experiments, since the disappearance of the released $\mathrm{SF}_{6}$ in the building is exponential. In the present series of experiments a purge time of 3 hours was required between experiments to clear the building of residual $\mathrm{SF}_{6}$.

The air and SF6 specimens taken at the several sampling locations were analyzed by a portable gas chromatograph having an electron capture cell fitted with a 300 mc radiation source. The response of the instrument to $\mathrm{SF}_{6}$ is exponential and the usable range is between 1 and $1,000 \mathrm{ppb}$. If dilution of samples is necessary, the usual syringe technique can be used.

Static pressures were measured by a Magnehelic pressure gauge of 0.01 to 0.5 inch $\mathrm{H}_{2} \mathrm{O}$ range.

\section{TEST METHOD AND}

INSTRUMENTATION-SMOKE DETECTORS

Prior to field testing, the smoke detectors provided in the building corridors were laboratory evaluated for sensitivity at different airflow velocities to provide data for correlating the field performance with laboratory sensitivity values. The tests were run at 15,50 and $150 \mathrm{fpm}$ airflow. 
Five detectors taken from the third floor corridor were tested in the NBS smoke test chamber, using pieces of punk as the smoke source. A description of the test procedure is included in a paper by Bukowski and Bright [16].

Two field tests of smoke detectors were conducted in the third floor corridor. As shown in figure 1, optical photometers Nos. 1 and 2, were installed at ceiling level near detectors 1 and 2, respectively. A third photometer was located in the corridor at a 3-ft height under detector No. 2, and near the exit to the stairwell.

The tests were run with 3 -minute smoke candles as smoke sources. In the first test, the candle was placed on the corridor floor in front of apartments $3 \mathrm{~B}$ and $3 \mathrm{C}$, at a point approximately 10 ft horizontally from detector No. 1. For the second test, the candle was located in the kitchen of apartment 3C. Due to the inclusion of self-closing apartment doors, as required by the Guide Criteria, the corridor door of the apartment was forcibly held open.

Light attenuation at the photometers was indicated on continuous strip-chart recorders that were actuated at the moment of initiation of smoke from lighting a candle. The photometers had a 1-1/2-ft light path. Attenuation of light due to smoke was translated to voltage attenuation through a photocell and amplifier. Voltage readings' were converted to optical densities.

\section{RESULTS \\ 5.1. Tests of Smokeproof Stair Towers}

The results of the two smoke movement tests are presented in tables 1 and 2 . The measured $\mathrm{SF}_{6}$ concentrations in terms of $\mathrm{ppb}$ and percent of burn-room concentration are tabulated for given times and locations. Other test variables and temperature variations are listed in the tables.

A comparison of the corridor and stairwell $\mathrm{SF}_{6}$ concentrations for corresponding times in test 1 indicates that the stairwell functioned well as a smokeproof stair tower except for a high level concentration of tracer gas at the 18 th floor. In the second test, where doors on 16 th and 17th floors were opened for exiting to the stairwell during the test, the accumulation of $\mathrm{SF}_{6}$ in the exitway became progressively worse to the point that the upper half of the stairwell was heavily contaminated. 


\subsection{Laboratory Tests of Smoke Detectors}

Results of the tests of smoke detectors made in the NBS laboratory are summarized in table 3. For each detector the smoke level at which it alarmed is tabulated for the three tested airflow velocities.

When tested at an airflow of $150 \mathrm{fpm}$, each of the five detectors met the recommendation for Operation BREAKTHROUGH acceptability that activation occur at a smoke concentration not greater than 0.01 optical density per foot. However, at $15 \mathrm{fpm}$ airflow, none of the detectors met the recommendation and three of the five failed to respond at $50 \mathrm{fpm}$.

\subsection{Field Tests of Smoke Detectors}

Results of the tests of the installed smoke detectors made in the third floor corridor of the building are presented in table 4. The smoke concentration at different times for each test is tabulated in terms of percent obscuration per foot (ob/ft) and optical density per foot (od/ft). In both tests, the smoke barrier doors were released upon actuation of the alarm by a detector.

Table 5 lists the visual observations for the two smoke detector tests. From these observations and the data in table 4 , the apparent sensitivity of the detector was 0.87 $\mathrm{od} / \mathrm{ft}(86.4 \% \mathrm{ob} / \mathrm{ft})$ for detector field test 1 , and 0.15 $\mathrm{od} / \mathrm{ft}(28.9 \% \mathrm{ob} / \mathrm{ft})$ for detector field test 2 . With the airflow velocity in both tests less than $10 \mathrm{fpm}$, none of the detectors was capable of meeting the sensitivity recommendations for Operation BREAKTHROUGH.

\section{DISCUSSION OF RESULTS}

The results of the tests with smokeproof stair towers indicated that the smoke moved generally upward, principally through the elevator shafts. For the inside to outside temperature difference of $26^{\circ} \mathrm{F}$, the upward movement appeared to be rather fast as indicated by the l6th floor corridor $\mathrm{SF}_{6}$ concentration of $27.5 \%$ at 5 minutes and 68.1 percent at 15 minutes.

The high level of $\mathrm{SF}_{6}$ found in the $18 \mathrm{th}$ floor stairwell was a cause of concern, as the smokeproof stairwell is not connected to the corridor by design. One explanation was that due to the proximity of the corridor vestibule door and the stairwell door (see fig. 1) it was possible to defeat 
the exterior venting feature if both doors were open simultaneously. It was noted that when a person exits from the corridor to the stairwell, the self-closing mechanism of both doors delays the closing, and allows both door openings to coincide for a period of time.

To check the possible effect of door opening overlap was the reason for the second smokeproof stair tower test. As noted in the results, there was a large concentration of $\mathrm{SF}_{6}$ in the stairwell, probably aggravated by the lack of a means of venting at the top of the stair shaft.

The poor sensitivity at low air velocities of the photoelectric type detectors installed in the building can be attributed to a smoke entry problem. Thus, with these devices the efficiency of smoke detection in the corridors of the building will be largely a function of the velocity of the smoke-laden air.

In the two field tests of smoke detectors, where air velocities were less than $10 \mathrm{fpm}$, actuation of the alarm by a detector occurred in approximately the same time. As the smoke concentration in the corridor in the first test developed much more rapidly than in the second, the detector sensitivity in the first test was much lower than in the second. This difference in sensitivity is believed to be due to the transient delay of smoke particles in entering the detector sensor chamber as smoke concentration continues to grow outside the smoke detector. In this way an apparent lower sensitivity value for the case of sudden heavy smoke evolution as compared to the case of more gradual smoke evolution could be expected..

In both field tests of smoke detectors, the alarm was actuated by the response of the first detector, which was the nearest to the smoke source. In the first test, photometer 3 , farthest from the smoke source registered 0.15 od/ft one minute after alarm, and reached a maximum of $0.23 \mathrm{od} / \mathrm{ft}$ at 10 minutes. The same photometer, in the second test showed a maximum of 0.1 od/ft after alarm for the duration of the test; photometer 2 did not register greater than 0.1 od/ft at one minute after alarm. The od/ft of 0.1 has been considered the upper limit of smoke concentration for human tenability, but this value is now considered by some to be too high, with a value on the order of $0.06 \mathrm{od} / \mathrm{ft}$ being suggested. 


\section{CONCLUSIONS AND RECOMMENDATIONS}

The following are the conclusions and recommendations resulting from this study:

1. The vertical movement of smoke through elevator shafts in a high-rise apartment building, with no smoke control measures, in the case of a simulated fire is very rapid. Using 2 percent burn-room concentration as a safety limit, the results indicate that the portion of the building above the neutral plane, approximately the midheight, is rendered uninhabitable after a duration of five minutes.

2. Smokeproof corridor doors actuated by smoke detectors can be effective if the pressure difference across the door due to the ventilation system is in the favorable direction, i.e., lower pressure on the fire side.

3. A smokeproof tower with an exterior venting vestibule of the type used in the building investigated may not be smoke free if there is a problem of door opening overlap in the vestibule. Possible remedies for this type of smoke accumulation in the tower is by top-venting which was incorporated in the test building subsequent to the final tests, or a detector actuated exhaust fan at top of the tower. Another method would be to speed-up the operation of the door closers so that the doors remain open for the least possible period of time. However, with a number of people passing through at one time, as in an emergency, it is probable that there will be overlap in the opening of the vestibule entry and exit doors, thus defeating the venting system. In this case, it may be necessary to give consideration to the use of pressurized vestibules to prevent the entrance of smoke.

4. As the sensitivity of the photoelectric type smoke detectors installed in the test building appears to depend strongly on airflow velocity, consideration should be given to changes in the aerodynamic entry design of the detectors to allow operation at the low air velocities normally encountered in building corridors, the use of another type of detector. 


\section{REFERENCES}

1. Hutcheon, N. B. and Shorter, G. W., Smoke Problems in High-Rise Buildings, ASHRAE Journal, 9 (1968).

2. Galbreath, M., Fire in High Building, National Research Council of Canada, Fire study No. 21. (1968).

3. McGuire, J. H., Control of Smoke in Building Fires, Fire Technology, Vol. 3, No. 3 (Aug. 1967).

4. McGuire, J. H., Control of Smoke in Building Fires, Fire Technology, Vol. 3, No. 4 (Nov. 1967).

5. Tamura, G. T., and Wilson, A. G., Building Pressures Caused by Chimney Action and Mechanical Ventilation, ASHRAE Transactions, Vol. 73, Part II (1967).

6. Tamura, G. T. and Wilson, A. G., Pressure Differences Caused by Chimney Effect in Three High Buildings, ASHRAE Transactions, Vol. 73, Part II (1967).

7. Barrelt, R. E. and Locklin, D. W. , Computer Analysis of Stack Effect in High-Rise Buildings, presented at ASHRAE 1968 Annual Meeting at Lake Placid, New York, (Àug. 1968).

8. Butcher, E. G., Fardell, P. J. and Clarke, J., Pressurization as a Means of Controliling the Movement of Smoke and Toxic Gases on Escape Routes, Joint Fire Research Organization Symposium No. 4, Movement of Smoke on Escape Route in Buildings, Paper 5, Watford, England, (1969).

9. Butcher, E. G. and Hall, M., Smoke Tests in New Law Courts Building, Joint Fire Research Organization Research Note No. 889, Borehamwood, England (1971).

10. Mechanically Ventilated Smoke Proof Enclosure, Los Angeles Fire Department, City of Los Angeles BFP and PA Requirement No. 56 (1970).

11. Butcher, E. G., Cottle, T. H. and Bailey, T. A., Smoke Tests in the Pressurized Stairs and Lobbies of a 26Story Office Building, CP 4/74, Building Research Establishment, Fire Research Station, Borehamwood, England.

12. Fung, Francis C. W. Evaluation of a Pressurized Stairwell Smoke Control system for a 12-Story Apartment Building, Nat. Bur. Stand. (U.S.), NBSIR 73-277 (June 1973). 
13. Hobson, P. J. and Stewart, L. J., Pressurization of Escape Routes in Buildings, Heating and Ventilating Research Association, Bracknell Berkshire, England.

14. Galbreath, M., McGuire, J, H. and Tamura, G. T., Exploratory Paper on Control of Smoke Movement in HighRise Buildings, NRC No. 11413, National Research Council of Canada, Ottawa, (1970).

15. Guide Criteria for the Evaluation of Operation BREAKTHROUGH Housing Systems, Department of Housing and Urban Development (HUD), Vol. 1, Multifamily High-Rise.

16. Bukowski, R. W. and Bright, R. G., Some Problems Noted in the Use of Taguchi Semiconductor Gas Sensors as Residential Fire/Smoke Detectors, Nat. Bur. Stand. (U.S.) NBSIR 74-591 (Dec. 1974). 
Table 1. Smoke Movement Test 1

\begin{tabular}{|c|c|c|c|}
\hline Location & $\begin{array}{l}\text { Time } \\
\text { (min) }\end{array}$ & $\begin{array}{c}\text { Concentration } \\
(\mathrm{ppb})\end{array}$ & $\begin{array}{c}\text { Percent } \\
\text { of } \\
\text { Burn Room } \\
\text { Concentration }\end{array}$ \\
\hline 4th floor corridor & 5 & 0 & 0 \\
\hline 4th floor stalr & 5 & 0 & 0 \\
\hline 4th floor corridor & 20 & 2.3 & 1.2 \\
\hline 4th floor stair & 20 & 0 & 0 \\
\hline 4th floor corridor & 50 & 5.8 & 3.0 \\
\hline 4th floor stair & 50 & 0 & 0 \\
\hline 5 th floor corridor & 6 & 0 & 0 \\
\hline 5th floor stair & 8 & 0 & 0 \\
\hline 5th floor corridor & 30 & 0 & 0 \\
\hline 5th floor corridor & 54 & 7.8 & 4.1 \\
\hline 6th floor stair & 44 & 0 & 0 \\
\hline 9 th floor stair & 47 & $\cdot 0$ & 0 \\
\hline 16th floor corridor & 5 & 53.2 & 27.5 \\
\hline 16th floor stair & 5 & 0 & 0 \\
\hline 16th floor corridor & 15 & 131.8 & 68.1 \\
\hline 16th floor stair & 17 & 1.5 & 0.8 \\
\hline 18th floor corridor & 30 & 137.9 & 71.2 \\
\hline 18th floor stair & 32 & 126.3 & 65.2 \\
\hline
\end{tabular}

Burn Room Location: Apt. $3 E$ in front of elevator Burn. Room Concentration: $193.65 \mathrm{ppb}$

Burn Room Over Pressure: $0.04^{\prime \prime} \mathrm{H}_{2} \mathrm{O}$

Burn Room Out Flow: $824 \mathrm{cfm}$

Temperature, Outside: $54^{\circ} \mathrm{F}$

Inside: $\quad 70^{\circ} \mathrm{F}$

Burn Room: $82^{\circ} \mathrm{F}$ 
Table 2. Smoke Movement Test 2 (Study of Door Openings)

\begin{tabular}{|c|c|c|c|}
\hline Location & $\begin{array}{l}\text { Time } \\
\text { (min) }\end{array}$ & $\begin{array}{c}\text { Concentration } \\
(p p b)\end{array}$ & $\begin{array}{c}\text { Percent } \\
\text { of } \\
\text { Burn Room } \\
\text { Concentration }\end{array}$ \\
\hline 4 th floor corridor & 5 & 0 & 0 \\
\hline 4 th floor stair & 5 & 0 & 0 \\
\hline 4th floor stair & 35 & 1.0 & 0.5 \\
\hline 4th floor corridor & 40 & 1.6 & 0.8 \\
\hline 10th floor corridor & 5 & 3.25 & 1.7 \\
\hline 10th floor stair & 5 & 0 & 0 \\
\hline 10th floor corridor & 15 & 10.5 & 5.5 \\
\hline 10th floor stair & 15 & 0 & 0 \\
\hline 10th floor corridor & 25 & 33.7 & 17.8 \\
\hline 10th floor stair & 25 & 4.1 & 2.2 \\
\hline 14th floor corridor & 35 & 58.1 & 30.6 \\
\hline 14th floor stair & 35 & 33.1 & 17.4 \\
\hline 14th floor corridor & 43 & 58.1 & 30.6 \\
\hline 14th floor stair & 43 & 47.2 & 24.9 \\
\hline 18th floor corridor & 47 & 87.9 & 46.3 \\
\hline 18 th floor stair & 47 & 94.6 & 49.8 \\
\hline 18th floor corridor & 55 & 120.3 & 63.4 \\
\hline 18th floor stair & 55 & 120.3 & 63.4 \\
\hline
\end{tabular}

Burn Room Location: Apt. $3 E$ in front of elevator

Burn Room Concentration: $189.8 \mathrm{ppb}$

Burn Room Over Pressure: $0.03 " \mathrm{H}_{2} \mathrm{O}$

Burn Room Out Flow: $870 \mathrm{cfm}$

Temperatures, Outside: $58^{\circ} \mathrm{F}$

Inside: $74^{\circ} \mathrm{F}$

Burn Room: $82^{\circ} \mathrm{F}$ 
Table 3. Smoke Detector Laboratory Tests

\begin{tabular}{|c|c|c|c|c|c|c|}
\hline \multirow{3}{*}{$\begin{array}{c}\text { Detector } \\
\text { No. }\end{array}$} & \multicolumn{6}{|c|}{ Alarm Points at Different Air Velocities } \\
\hline & \multicolumn{2}{|c|}{$15 \mathrm{fpm}$} & \multicolumn{2}{|c|}{$50 \mathrm{fpm}$} & \multicolumn{2}{|c|}{$150 \mathrm{fpm}$} \\
\hline & $\mathrm{od} / \mathrm{ft}{ }^{*}$ & $\mathrm{ob} / \mathrm{ft}{ }^{* *}$ & $o d / f t$ & $\mathrm{ob} / \mathrm{ft}$ & $o b / f t$ & $o b / f t$ \\
\hline 1 & 1.061 & $13.09 \%$ & 0.0068 & $1.55 \%$ & 0.0044 & $1.0 \%$ \\
\hline 2 & 0.056 & $12.10 \%$ & 0.0029 & $0.67 \%$ & 0.0019 & $0.44 \%$ \\
\hline 3 & 0.107 & $21.77 \%$ & 0.048 & $10.42 \%$ & 0.0050 & $1.15 \%$ \\
\hline 4 & 0.106 & $21.72 \%$ & 0.014 & $3.08 \%$ & 0.0064 & $1.46 \%$ \\
\hline 5 & 0.058 & $12.50 \%$ & 0.011 & $2.61 \%$ & 0.0028 & $0.65 \%$ \\
\hline
\end{tabular}

od - optical density

** ob - obscuration 


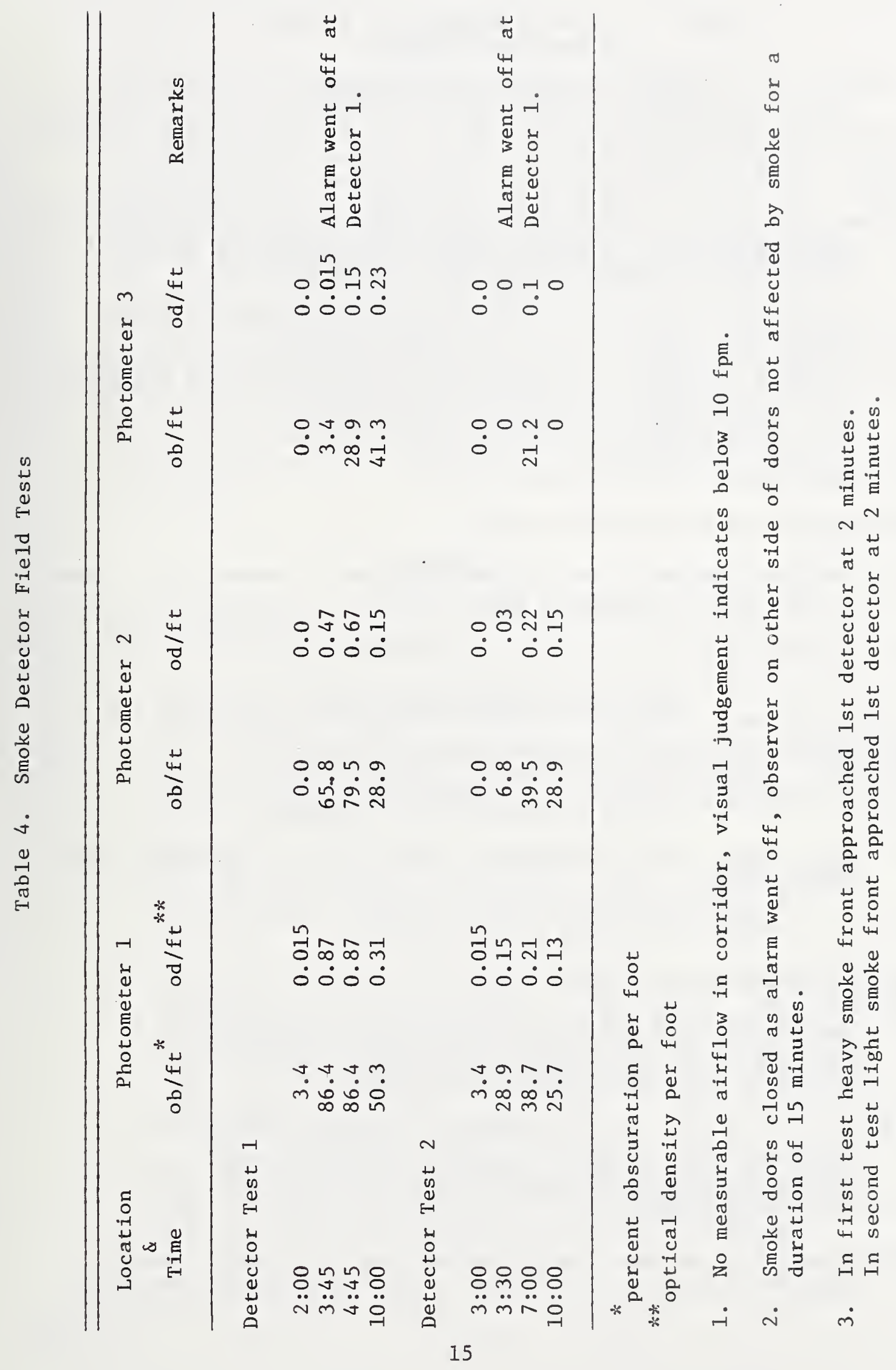


Table 5. Visual Observations of Smoke Detector Field Tests

Test 1 - High Smoke Level Time

Time

min:sec

Observations

0:0 Smoke candle lit, located in front of Apartments $3 \mathrm{~B}$ and $3 \mathrm{C}$ at floor level, distance to detector 1 about $10 \mathrm{ft}$.

1:00 Heavy smoke immediately in area adjacent to smoke candle.

2:00 Movement of smoke front towards first detector at low velocity, very little diffusion observed at this point. Velocity of smoke front less than $10 \mathrm{fpm}$.

3:00 Heavy smoke surrounding detector 1.

3:45 Alarm went off at detector No. 1 .

5:00 Gradual movement of smoke, also diffusion of smoke front. Smoke contained by closed smoke barrier door.

10:00 Maximum smoke level reached at photometer 3.

Test 2 - Low Smoke Level Test

0:0 Smoke candle lit inside Apartment 3C kitchen.

1:00 No visible smoke out of Apartment 3C door yet.

2:00 Light smoke slowly approaching first detector at velocity less than $10 \mathrm{fpm}$.

2:50 Light smoke approaching second detector.

3:30 Alarm went off at detector No. 1 .

7:00 Smoke diffused and filled coridor, however, contained to one side of closed smoke barrier door. Smoke intensity is at a maximum at this point.

10:00 Smoke intensity leveling off due to leakage through apartment and stairwell. Observer on other side of corridor protected by smoke barrier door still not affected by smoke.

15:00 Termination of test, smoke barrier door effectively protects observer on other side of door. Only light smoke infiltrated. 


\section{APPENDIX A}

Definition of "smokeproof stair enclosure," Criterion L.4.2.9, Vol. I, Operation BREAKTHROUGH Guide Criteria.

"A stair enclosure so designed that the movement of products of combustion, produced by a fire occurring in any part of the building, into the smokeproof stair enclosure, should be limited by the use of an appropriate design method to ensure that with the minimum winter exterior dry bulb temperature (based on the ASHRAE design tables for $97-1 / 2$ percent probability for the geographical location of the building), the atmosphere in the stair enclosure should not, during a period of two hours, develop a contaminated atmosphere emanating from the fire area that is more than one (1) percent of the volume of the smokeproof stair enclosure."

\section{APPENDIX B}

Other safety provisions incorporated in lieu of exit stairway separation:

1. Single-station-type smoke detectors should be installed in the two end apartments, one apartment at each end of the building; having travel distances greater than 50 feet within the apartment. Because of the apartment length, two smoke detectors in each apartment would be necessary.

2. The building areas on either side of the smoke barrier doors should have separate heating, ventilation and air conditioning services.

3. Apartment doors should be Class B, one-hour fireresistance doors with $250^{\circ} \mathrm{F}-30$-minute temperature limits. Door frames should also be "labeled". Doors should be tight-fitting with no more than 1/8-inch clearance at the top and sides and 3/4inch at the bottom. The doors should be equipped with self-closing devices.

4. The wall between the stairwells should be 1-1/2hour in fire resistance and carried through to the corridor wall between the elevator shafts. 


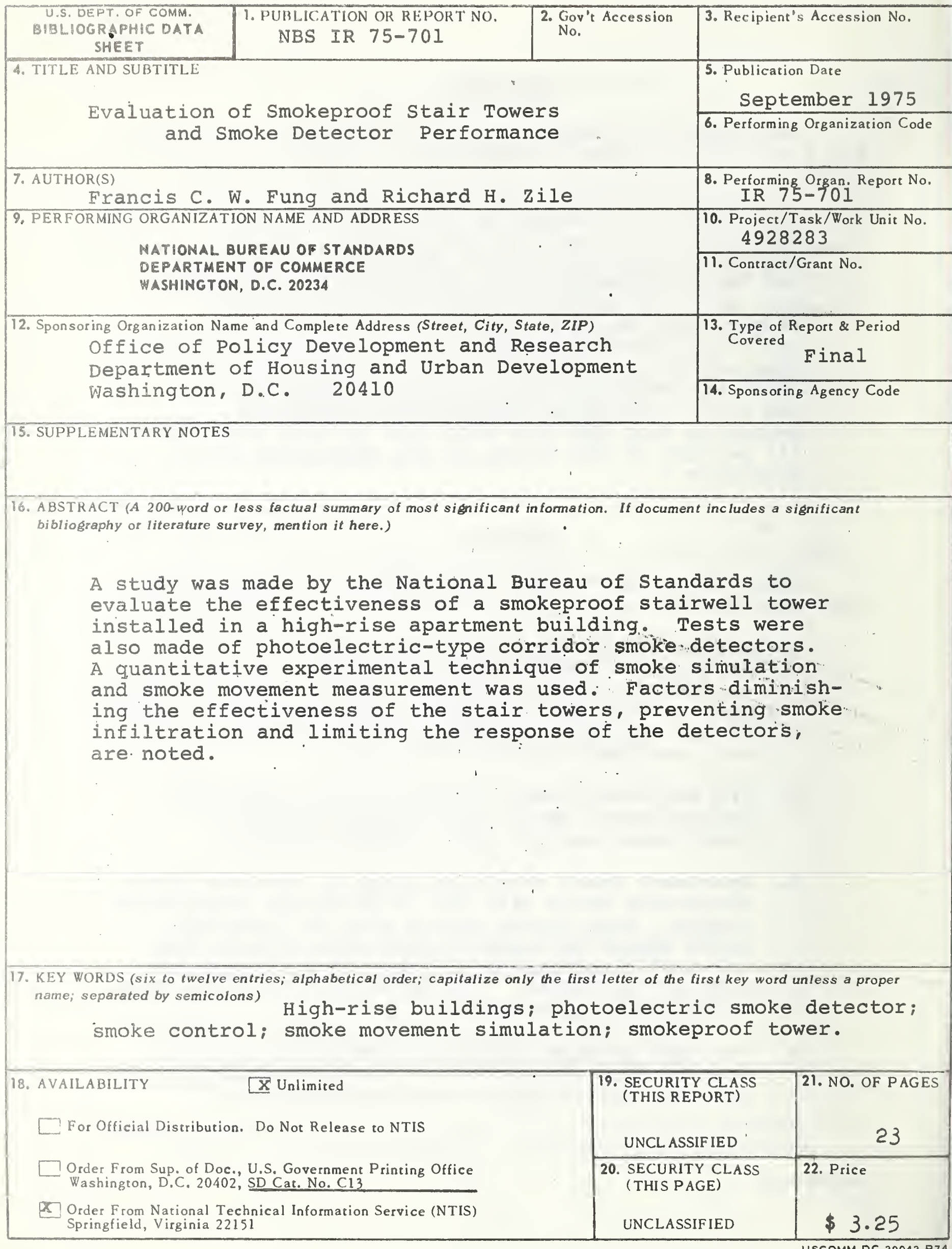



